\title{
Asian Infrastructure Investment Bank (AIIB) as an Instrument for Regional Leadership of China in the East Asia Region
}

\author{
Anggara Raharyo \\ School of International Relations Study Program \\ President University \\ Indonesia \\ Anggara.raharyo@president.ac.id
}

\begin{abstract}
Abstrak
Pembentukan Bank Investasi Infrastruktur Asia (AIIB) telah menimbulkan banyak kontroversi dan debat semenjak diumumkan pada tahun 2013 lalu. Para peneliti banyak memeplajari alasan pembentukan AIIB. Banyak dari peneliti tersebut melihat pembentukan AIIB sebagai usaha Tiongkok untuk menggantikan Amerika Serikat sebagai hegemoni dunia. Akan tetapi, melihat kebijakan luar negeri Tiongkok dalam beberapa decade terakhir, pembentukan AIIB adalah hal yang biasa dalam usaha Tiongkok menjadi 'leader' di dalam regionalisme Asia Timur. Tulisan ini menyimpulkan bahwa Tiongkok masih hanya mengincar posisi sebagai 'regional leader' di kawasan Asia Timur.
\end{abstract}

Kata Kunci: Asia Timur, Regionalisme, Leadership, Tiongkok, AIIB

\begin{abstract}
The establishment of the Asian Infrastructure Investment Bank (AIIB) has sparked many debates and controversies in the last five years since it was announced back in 2013. Amongst studies trying to explain the reason for the establishment of the AIIB, most of them are based on the analysis of Sino-U.S. relations especially on how they overlooked China as a replacement for global hegemon to the U.S. However, considering China's foreign policy in the recent decade, the establishment of the AIIB is considered as a typical step to becoming a leader in regionalism of East Asia. This writing concludes that China is still only aiming to become regional leader in the scale of East Asia.
\end{abstract}

Keywords: East Asia, Regionalism, Leadership, China, AIIB

\section{Background}

The establishment of the Asian Infrastructure Investment Bank (AIIB) has sparked many debates and controversies in the last five years since it was announced back in 2013. President Xi Jinping, in his early administration, during his visits to Indonesia announce their plan to establish a regional financial institution that aims to improve interconnectivity and regional economic integration thus bring wealthier condition in the regional economic condition. The bank finally came into a full operation in 2016 January and still a lot of studies - especially those who are concerned with the future of economic and political development of East Asia pays attention-that focuses on AIIB's establishment. 
The most common topic discussed in recent studies is the motive and reason of the establishment of the AIIB. Scholars generally point out at least four main reasons for the establishment of the AIIB.

First, China focus on infrastructure bank development is to share an experience as China hopes it can be a model for economic development in Asia. As China felt that the development of infrastructure may boost economic development in the nation (Ren 2016).In the Article of Agreement (AOA) of the AIIB itself, it is mentioned clearly that:

ACKNOWLEDGING the significance of infrastructure development in expanding regional connectivity and improving regional integration, thereby promoting economic growth and sustaining social development for the people in Asia, and contributing to global economic dynamism;(AIIB, 2016)

Second, the establishment of AIIB will help to match Asia's demand for infrastructure development. As a growing region, Asia needs to focus their infrastructure development to prevent a stagnant economic growth. An improved infrastructure will then lead to better distribution and hoping to increase trade and other economic sectors. Estimated by Asian Development Bank (ADB) that Asia region will require USD 8 trillion annually (ADB, 2013).

Third, China creates AIIB to accommodate their economic power and underrepresentation in the international financial institution(Kawai2015; Chow 2016; Ren 2016). The international financial order is dominated by the U.S while China's economic size has rapidly increased and came second just after U.S's economy. In the Bretton-Woods regime, however, China's growth has not been accommodated well by U.S. Two main institutions within the regime, the World Bank and the International Monetary Fund (IMF), where China's position is considered insignificant compared to their current economic size. The only recent improvement of China's position is the inclusion of Renminbi into the Special Drawing Right by the final quarter of 2015 .

Fourth, the establishment of AIIB as a response to U. S's pivot to Asia policy. The other policy that is also considered as a response for the pivot to Asia policy is also the 'One BeltOne Road' initiative and hand-to-hand with the AIIB program of developing infrastructure. Both programs were trying to increase China's position to balance the pressure brought by the US's policy. The Pivot to Asia policy, according to China, has five main goals that is to: contain, isolate, diminish, sabotage and divide China's role in the region (Åberg 2016). The presence of AIIB will at least help to soft-balancing U.S's policy in Asia(Chan 2017).

In short, amongst studies trying to explain the reason for the establishment of the AIIB, most of the mare based on the analysis of Sino-U.S relations especially on how they overlooked China as a replacement for global hegemon to the U.S. 
One example is the thesis concludes that establishment of AIIB is trying to delegitimize U.S. primacy in Asia and any U.S led institution by the democratization of financial institution with the end goal of weakening the U.S. Hegemony (Park 2017). The reason behind this is one of the distinctions of U.S. led financial institution compared to the AIIB, is the membership representation of countries within the region. AIIB limit the countries from outside the region to only 30 percent of the total shares. Thus, it creates more space for the members in Asia to contribute or receive better funding from the Bank.

Compared to the closest Multilateral Development Bank that operates in Asia, the ADB that is mainly dominated by Japan and U.S having the same shares amount of 15.6 percent (ADB , 2017) with other countries mostly European countries dominating the shareholders AIIB can offer a better space for the Asian members. In addition, the exclusion of the U.S. gives more space for the Asian member to be able to establish a more independent financial institution without the U.S involvement. In the end, the absence of U.S in a regional institution - where in most Asian institution, the U.S. often plays a significant role - will decrease the needs on U.S. involvement and leads to weakening of the U.S. hegemony.

The similar argument also can be found in many studies that consider the AIIB as one of China's movement to become a leading hegemon in global politics. However, considering China's foreign policy in the recent decade, the establishment of the AIIB is considered as a typical step to becoming a leader in regionalism of East Asia.

There are three main reasons that the establishment of AIIB is considered as only an effort to become a leader in the East Asia Regionalism: (1) China establishment of the AIIB is considered as providing public goods for the region, which is one of the key elements of becoming if not the only leader, one of the leaders in forming regionalism. (2) China has been trying to become a leader of the region since opening multilateral relations with ASEAN countries. (3) Governance and membership structure of the AIIB that is giving more space for the Asian countries to contribute better in the international financial regime is a move to show and attract the region and accepting China as the leader of the region.

This writing aim is to prove that China's effort is a usual arrangement of policy for a country to gain acceptance and followers from the region of East Asia. While many researchers focus on its rising power and how it will challenge U.S hegemony in the world, this writing will try to show that China's rising power is still aiming for regional power and still far from being a global power. It also aims to contribute to the study of rising power and testing the model of the process of rising power, therefore will give an improvement of the study in rising power.

In proofing that China's reason for establishing the AIIB is due to their interest to perform a leadership role in regionalism of East Asia, this writing will be separated into five parts. The next part will try to discuss and explain the concept of Leadership in regionalism. The third part will consist of several efforts that have been done by China in becoming the leader of the region continued with the explanation of the AIIB as a tool to firm its position in the region. The final part will conclude this writing. 


\section{Leadership in Regionalism}

The concept of leadership is one of a newly developed concept in the field of regional studies and international relations, especially in the post-World War II. In general, it has a close relationship with the well-known concept of 'Hegemony'(Destradi 2010). However, unlike hegemony concept, the leadership concept is not merely based on traditional belief in power. There are at least three models on understanding in the concept of Leadership.

The first model believes that a leader usually possesses a high degree of tangible power or hard power. A huge number of military personnel, large territory, and economic capability determines a country's hard power (Gallarotti 2015). The first model also believed that the presence of global governance is zero ( $\mathrm{Vu}$ 2017) therefore, a leader is equal to hegemon concept in the definition.

The second model believes that leadership will be based on a country's initiative upon certain common problems or can act as a mediator in any problems between the members. This model usually related to a leaders' responsibility to provide public goods. Unlike the first model, the second model is open to countries without a high level of hard power. It opens the chance for smaller or secondary countries to take chance as a leader in the region or, which brings us to the third model, the cooperative model.

The third model or cooperative model believes that leadership can be bare by more than one country. It has the same belief as the second model that a leader does not rely on hard power. In addition, the third model emphasizes the importance of acceptance or consent by other countries that one or several countries plays important role as leaders (Keohane, After Hegemony: Cooperation and Discord in the World Political Economy, 1984).

In summary, the three models of Leadership put a highlight on the role of Leader to be able to solve common problems, creating stability both military and development through public goods provision, and be accepted by other nations as a leader as well.

\section{Leadership role in Regionalism}

Regionalism formation, in general, requires a 'supply-demand 'side, without the existence of one another the process of regionalism is incomplete. The demand side is indicated by groups or individuals who demand a regional institutionalization movement, usually those who have the interest to reduce tariff and non-tariff barriers and reduction for the transaction cost. Meanwhile, the Supply side is indicated through a good "political mechanism to provide leadership, aggregate interests, and convert them into policy” (Choi, 2007).

The subscriber to the concept of leadership in regionalism believes that the presence of leadership - unilateral or cooperative - will be able to increase and guide a regional integration (Pedersen, 2002; Ba, 2014). In relations to the 'supply-demand' concept in regionalism, the presence of leadership shall be able to lead persuade the states by means of 
solving common problems, regional stability, providing public goods, and acceptance by another country to take the role as the leader.

In addition to the requirement based on the three models, a leadership in regionalism also should be able to perform a regional level institutionalization and representing a regional interest in global politics (Dent, What region to lead? Developments in East Asian regionalism and questions of regional leadership, 2008). Creating institution or regime in regional is considered critical as it will ensure acceptance of leadership of a country or more to a system or idea that is created by the leader. As mentioned, acceptance by other countries, or 'followership' (Dent, 2008) is considered a critical policy for regional leaders (Pedersen, 2002).

\section{The process of leadership}

After understanding the basic concept of leadership and their role in creating regionalism, one will try to understand the process of becoming a leader in the region. The leadership process model that is suitable to answer the research question created by $\mathrm{Vu}$ (2017). It is mentioned that leadership in emerging countries shall cover four level. The first one is when a country obtains materials to be able to influence follower by other countries. Materials can be defined as power especially in economic terms, whether it has a significant development over the years or any incentives given that will be able to convince other countries to follow the emerging countries. However, having huge economy will not automatically define an emerging country as a leader in the regionalism process.

Therefore, second, the emerging power shall utilize their owned materials to create program or projects that shall represent and able to fulfill other states demands. The projects shall function as a key entry point of an emerging country to declare its intention to become the leader. It also can measure other states response upon the projects created as a level of acceptance or recognition of the (new) leadership.

Third, after the acceptance of other states, it will create a hierarchical position in the region. The leader then shall be able to introduce the new value and norm that will be recognized by other states and ultimately justify the leader's position within the region. Some states who do not comply or accept the projects of emerging power will be excluded from the new coalition and if the state who does not follow is secondary compared to the emerging in terms of material, then it might have the consequences of building its own network of a coalition with other states. Therefore, any emerging power shall consider the secondary states support in obtaining leadership position within the region.

Fourth, after leadership status is obtained, it then can be analyzed how the new leader's position into several types. According to this model, there is six types: (1) Hegemonic position: it refers to a position where the emerging power is taking a leadership unilaterally. (2) Sharing position: whenever the emerging power comes to take leadership position, it must face the existing or a country's unacceptance to the leadership role taken by the emerging power. (3) Anarchic position: it refers to the position where the region does not have a single 
leadership role therefore creating an anarchic position. (4)Rivaling position: refers to circumstances where two or more leaders fight to gain dominance in the region. (5) absence position: refers to the condition where there is no emerging power in the region and leadership is controlled by existing powers.

In addition, Dent (2008) elaborate leadership scenario where two countries are trying to take a leadership position - in his scenario Japan and China - into six types. (1) contested leadership: a condition where two countries seeking domination against another. (2) division of labor: sharing of roles between two countries by sharing some tasks. (3) General CoLeadership: both countriescreates alliance as in France-Germany relations in forming European union. (4)Alternative co-leadership: One of the leaders cooperates with secondary state within the region to overcome two main emerging power. (5) Coalitional Leadership: both power seeking cooperation with other country to solve on several or issue. (6) Group Consensus Leadership: none of the emerging countries successfully take on the leadership position and instead a group consensus between countries take on leadership position based on problems.

The leadership concept analysis in regionalism process is critical especially in the case of a region in which each country has similar material capacity. The leadership concept will be able to explain the dynamic politics in the region and will be able to analyze each policy's interest in regionalism. However, to understand the dynamic, the actors of emerging powers in the region and their role in regionalism shall be understood. Therefore, in the next part, the writer will focus on explaining East Asia regionalism in general, it then looks upon China's specific role as emerging power and contribution to the East Asia regionalism. In addition, it will also look on China's - head to head - relations with Japan in East Asia regionalism.

\section{China's Effort as the Leader in East Asia Regionalism}

To understand China's effort to become a leader in East Asia region, we should see how the regionalism process of East Asia in the beginning by looking at their institution building. We should track back to the Post-World War II where the nations in East Asia regions start to gain their independence and seeking to develop their economic condition.

East Asia that consists of at least two sub-regions, Southeast Asia, and Northeast Asia, had a different condition in the Post-World War II. The northern counterpart is dealing much with conflict of Korean War and development of each nation, causing nations in Northeast Asia to focus on stabilizing domestic politics. Meanwhile, the southern part is considered a newly independent state with Thailand, Malaysia, the Philippines, and Indonesia, at least has a better condition in national stability and ability to engage in international relations with their neighbors. The formation of Southeast Asia Treaty Organization (SEATO) is the first sign of regional institution building in Southeast Asia, continued with Association of Southeast Asia (ASA) and Maphilindo in the year of 1954, 1961, and 1963. However, the early movement was temporary and quickly dissolved not long after their establishment. 
In 1966, with the improvement of the economy of Japan, they lead with the creation of Asian Development Bank (ADB). The main distinctive character of ADB and previous organization is while others are focused on security, the $\mathrm{ADB}$, focus on economic development. Even the next organization that is developed, the Association of Southeast Asia Nations (ASEAN) in 1967, is based on security reason that is: preventing communism spread in Southeast Asia and preventing Indonesia to use coercive as a foreign policy instrument (Jones \& Smith, 2006).

The idea of wide regional cooperation is not developed until 1989, the end of cold war, where Asia-Pacific Economic Cooperation (APEC) was formed. It involves wider economic cooperation and for the first time covers countries in East Asia. This forum was the first time where the region of East Asia met.

The APEC meetings triggers, then Mahathir Mohammad the Prime Minister of Malaysia to form East Asia Economic Grouping (EAEG) that will exclusively create an economic cooperation between ASEAN and China, Japan and Korea or the East Asia region in general. However, this initiative is then rejected by the ASEAN members due to unattractiveness compared to APEC FTA (Kim, Ping, \& Ariff, 2011).

The East Asian regionalism simply stalled with the rejection of EAEG and financial crisis in 1997. Although the result of the financial crisis is devastating, it has at least four effects for the regionalism in East Asia: (i) realization by East Asian countries that their economic activities are deeply related and dependent on each other. (ii) lose of confidence of US-led international organization such as IMF and even APEC. (iii) The rise of China's economy and interdependence of East Asian economic causes China to engage more in East Asia. (iv) regionalism of East Asia emerges in the form of ASEAN Plus Three (APT)(Lloyd \& Lee, 2001; Park Y.-i. , 2007; Park \& Kim, 2006; Lee \& Cheong, 2011; Dent, East Asian Regionalism, 2008).

\section{China in East Asia Regionalism}

China first engagement occurs during APEC meetings; however, it is not until 1997 then China officially has a formal institution. Formation of the APT is expected to solve - and to certain extend - to prevent the financial crisis in 1997 resulted in a similar magnitude in the future. One solution for the issue is to create a regional financial institution that is not in the form of Bank. The East Asia region, with Japan's accent, has created a financial institution that aims to develop their member's economy and shifted in the1990s to develop regional cooperation (Dent, The Asian Development Bank and Developmental Regionalism in East Asia, 2008), the ADB. However, in the international financial institution, it exists another kind besides the bank that is the IMF that has the task to recover a country's monetary condition, especially during an economy crisis.

Japan came up with the first solution that is the creation of Asian Monetary Fund that adopts similar approach to the creation of ADB in hand with the World Bank institution. However, the idea was rejected by most of the APT members because a strong endorsement from 
Malaysia and China to create an independent financial institution from the IMF (Lee \& Cheong, 2011; Haacke, 2002).

The APT then came up with the initiative for developing an institution for bilateral currency swaps mechanism so that the region will be less dependence on U.S. Dollars exchange. The initiative is called the Chiang Mai (CMI) Initiative that is established in the year 2000.This initiative is highly supported by China because of two reasons: first, the creation of independent financial institution will be able to reduce U.S influence in the region; second, the AMF initiative by Japan is believed to give Japan advantage position by strengthening their Yen currency (Park J.-S. , 2012).

After the CMI creation, China then tries to give more incentive to the region by finalizing the ASEAN-China Free Trade Area (ACFTA). The initial agreement was signed in 2002 and then finalized in 2010 (ASEAN, 2015). Agreement on ACFTA is a leap forward in East Asian regionalism and for China as well. It is the first FTA agreement between China and overseas entity, and the first ASEAN FTA agreement with other countries outside the membership of ASEAN (Nakamura, 2009). It then also drives the relationship between ASEAN member states and China bilateral relations ( Vu 2017). ACFTA is a clear indication that China has generated a great influence on the region by offering access to Chinese large market for the ASEAN members.

Having the advantage in leading the regionalism, China then, tried to support the creation of a more exclusive or the "main channel of East Asian region cooperation" (Haacke 2002). The creation of East Asia Summit (EAS), in 2005, it was meant to create a framework of regionalism in East Asia that is more independent from the U.S and will be able to give more roles to China. Most existing East Asian regionalism is heavily centralized and dependent on the ASEAN organization framework (Chung, 2013). However, Japan proposed a different approach that is to widen the membership followed by Australia, New Zealand, and India joining the EAS and the inclusion of U.S and Russia in the EAS membership.

The failure of China to create an exclusive East Asian organization is doomed with ASEAN members in the EAS prefer a wider regionalism instead an exclusive (Chung, 2013). The region of East Asia, as can be seen, depends on the followership of the ASEAN member states loyalty to an initiative. China's relations with the ASEAN members have improved significantly. It moves from suspicious relations between ASEAN and China into a cooperative regionalism (Haacke, 2002). The creation of ACFTA is a leap forward for the leadership role of China, in addition to the inclusion of China in the APT framework. It proves that China has always tried to create a program that ensures followership of the ASEAN members and with the creation of EAS, China, has lost one point that ensures their position in the region.

Sino-Japan relationship in East Asia Regionalism 
Unlike China, Japan presence in the ASEAN states has existed long before the China rise. Japan has been dominant with their material capability and even lead the regional economic development through "FDIs as a package of capital, technology, managerial skills and market"(Park Y.-i. , 2007). The early stage of Japanese presence of leadership in the region is the formation of the ADB. The ADB announce Japan's position as the most developed country in the region and aims to influence other countries to follow their economic development model (Rathus, 2008).

The rapid growth of China has caused them to no longer dependent on the ADB's fund - that has been used as one of Japan's program in leadership - and threaten Japan's dominant position in the region. Especially after the 2006 USD 2 billion soft loan by China to the Philippines - host of the ADB - Japan then start to consider China as a competitor in gaining leadership in the region of Southeast Asia.

During the financial crisis, Japan proposed the idea of AMF to solve the issue. The reason it fails, however, is due to China's fear of stronger Yen position in the region and opposition from extra-regional entities(Park J.-S. , 2012). While China's role in opposing this program is passive, China main ally, Malaysia step forward to resist most of Japan's program(Lee J.-S. , 2004; Jones \& Smith, 2006; Dent, East Asian Regionalism, 2008).

When China established the ACFTA, Japan tried to tackle with its bilateral trade agreement. Even so, the bilateral trade agreement between Japan and ASEAN members failed to create an effect on Japan's leadership position. Meanwhile, China's ACFTA contributed to the development of the regionalism in East Asia which also means ensuring followership of Chinese leadership in the region (Dent, 2008). One of the reasons that ACFTA is followed by other ASEAN states member is that China offers to open agricultural products which are the main commodity of ASEAN states members, while Japan is reluctantly opening its agricultural and fisheries market (Zha, 2002; Chung, 2013).

The strongest and ongoing form of a competitive program for leadership is in the formation of regional architecture that leads the East Asian regionalism. At the present, there are two forms of regional architecture to develop the East Asian regionalism, one is the APT; the second is EAS. The main difference between those two forms is the membership, while China prefers the APT as it forms deeper regionalism; the latter, supported by Japan aiming for wider regionalism.

Both China and Japan have a very competitive nature in gaining followership from the ASEAN member states. In relations with the established theoretical framework, we can conclude two arguments. First, the condition of leadership in East Asia that is led by Japan or China is seeking to establish themselves in a hegemonic position. Therefore, second, both countries are in the condition of contested leadership.

In the condition of contested leadership, each country will try to make a program to be able to attract followers by other states. Each party will try to make better programs than the others 
only to gain attraction. In the case of China, the EAS - especially with the U.S officially joined the institutions - is considered as a failure of diplomacy ( $\mathrm{Vu}, 2017)$.

China, then, must create a new program that will attract the region in East Asia. As a latecomer in the game, China has the option to replicate but better programs than Japan's. If we look on Japan's program for leadership, it is mainly on creating economic development programs such as Foreign Direct Investment (FDI) and Official Development Assistance (ODA). However, one thing that has not been done by China is creating an international bank-level institution or multilateral development bank (MDB). MDB creation is an essential program in Japan's step to lead the regionalism of East Asia. It attracts in a way by providing enhancement to "economic capacity and prospects of less developed countries with the view of strengthening their integration into the regional economy, and thereby bringing greater coherence to regional community building overall'(Dent, 2008); or in other words, the ADB helps to 'provide the public goods' in the region.

\section{AIIB as a program for Leadership in East Asia}

Limits of $A D B$

$\mathrm{ADB}$, as mentioned, has been long standing as it provides public goods for the region of Asia. In short, ADB function as the World Bank's Asian 'branch'. The programs and policies are similar such as the hard loans from the Ordinary Capital Reserves (OCR); soft loans from the Asian Development Fund (ADF); and technical grants from the technical assistance fund (Lincoln, 2004). Until the 1990s, ADB programs focus on poverty eradication and economic development in a country, it then continues to put more attention to regional cooperation (Dent, 2008).

The ADB, however, they put effort to attract countries in ASEAN region, has two main limits. First, their resources are limited and shall separate funds to other parts of the region as well. It is estimated that Asia needs 8 trillion USD annually for the next ten years (ADB, 2013). The ADB only needs around 160 billion USD annually. ${ }^{1}$ Therefore, in fulfilling the needs for the Asian economic development, a bigger contribution from emerging power such as China will help. The increasing demand for economic development gives room for supplying it with loan program. Although China has the option to do bilateral loan - similar to the 2 Billion loans for the Philippines - China prefer to do in the form of institution. The same case when China pursued free trade area, instead of having a bilateral agreement - like Japan did -China opted for ACFTA which is a multilateral framework cooperation.

The second limitation of the ADB is the structure of the organization that consists of: shareholders and loan decision-makers. Shareholders ratio weight much on members outside of the region, especially the U.S. ADB's main shareholders are Japan and U.S, each owns $15.6 \%$ of shares (ADB, 2016). Therefore, funding related policies in the region of Asia will depend on approval by Japan and the U.S. or in short, the structure of the shareholders in the

\footnotetext{
${ }^{1}$ More infographics related to the Asia's infrastructure gap is accessible in: https://www.adb.org/news/infographics/who-will-pay-asias-8-trillion-infrastructure-gap 
ADB heavily relies on the U.S. Not only the shareholders, the President of ADB, as always, are taken from Japan's Ministry of Finance (Dent, 2008). The flaw in the shareholder's ratio gave a room for China to create a program that will, at least, reduce the dominance of a country outside the region.

The loan process of ADB heavily relies on their Board of Director approval ${ }^{2}$ that has a resident status. It means that the Board of Director of the ADB will meet regularly and take decision for loan approval and it could mean it will take longer process. This limitation gives room for improvement in cutting bureaucracy process and accelerates loan process. One of the alternatives is to form the Board of Director as a non-resident. This practice has been done in the Andean Development Corporation (CAF) that delegates authority of loan approval to the President, therefore, accelerating loan procedure.

As we see, the existing MDBs in the region of East Asia still leave room for improvement. The demand from its member to gain more loan, as the economic condition increases the shareholders structure that is highly participated by the U.S; and, loan-process that can be faster than ADB. The creation of AIIB, therefore, shall at least utilize the limit of ADB and can offer a better or at least similar feature of the ADB.

\section{AIIB advantages}

On29 June 2015, AIIB is formally established with 57 founding members. The set of rules that controls AIIB operation is the Article of Agreement (AIA). Although AIIB invites U.S and Japan to join founding members, they decline and until recently, both also not seen in the prospective members of the Bank. ${ }^{3}$

The AIIB's capital stock is set to be one hundred billion US Dollars (US\$ 100,000,000,000). Although, the number is very far from the region's demand of US\$ 8 trillion, an increase to the existing MDBs option will be a relief addition for the East Asian members. The number of capital stock is also smaller than the ADB that is US\$163,5 billion. Yet in the case of the region's financial gap, any number will be enough to attract followership of the others. Except for Japan and DPRK, every country in East Asia joins the AIIB. It proves that the program is well accepted by the countries in East Asia, although Japan, a competitor, still opposing to the program of AIIB establishment.

Table 1 ADB Compared to AIIB

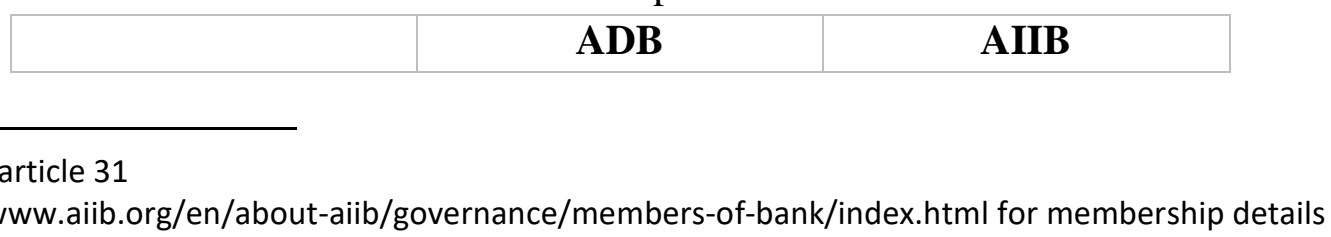


Anggara Raharyo

\begin{tabular}{|c|c|c|}
\hline Year Established & 1966 & 2015 \\
\hline Headquarters & Manila, Philippines & Beijing, China \\
\hline Member Countries & 67 & $61^{4}$ \\
\hline $\begin{array}{c}\text { Capital } \\
\text { Subscription }\end{array}$ & US $\$ 163.5$ billion & US\$ 100 billion \\
\hline Major Shareholders & $\begin{array}{l}\text { Japan, US, China, } \\
\text { India, Australia }\end{array}$ & $\begin{array}{c}\text { China, India, Russia, } \\
\text { Germany, ROK }\end{array}$ \\
\hline Voting Shares & Regional: $65 \%$ & Regional: $75 \%$ \\
\hline Board of Directors & Resident & Non-Resident \\
\hline $\begin{array}{c}\text { Loan Decision- } \\
\text { Makers }\end{array}$ & Board of Director & $\begin{array}{l}\text { Board of Director } \\
\text { with option to } \\
\text { delegate to the } \\
\text { Bank's President }\end{array}$ \\
\hline
\end{tabular}

Source: (Kawai, Asian Infrastructure Investment Bank in the Evolving International Financial Order, 2015) and writer's compilation

The AIIB has a different approach toward shareholders portion. In the ADB, the regional members are only able to obtain $65.1 \%$ of shares. While the AIIB, at least, give a larger space that stands in at least $75 \%$ and the non-regional members only hold a maximum of $25 \%$ of shares. The main shareholders of the non-regional member are Germany (4.3\%), France (3.2\%) and the United Kingdom (2.9\%) (AIIB, 2017). Compared to the ADB, U.S holds same share amount as Japan that allows high interference by the US in the Bank's operational (Wan, 2016).

Another advantage is that is exploited through ADB's limitation is the formation of the Board of Directors. As can be seen in (Table 1), the Board of Director is not residential in the AIIB, therefore they are open to the option to delegate the loan decision making to the Bank's President. It will mean that the funding application process will be faster compared to the ADB's which is needed by developing countries who seek loans from the bank. In a similar structure, the CAF who adopt a non-resident Board of Directors and delegate the decisionmaking process to the President of the Bank usually only require three to five months of the process (Kawai, 2015). It is expected that the AIIB will be able to perform similar speed in managing loans process.

\footnotetext{
${ }^{4}$ Additional 11 members admitted in 2017. More info: https://www.aiib.org/en/aboutaiib/governance/members-of-bank/index.html

${ }^{5}$ As per March 2017, the Operational Policy on Financing document stated that "each financing is approved by the Board (Board of Director), or as delegated by the Board to the President (of the bank)." More on: https://www.aiib.org/en/policies-strategies/ download/operationpolicy/policy operational financing new.pdf
} 
Table 2 Top five voting powers in East Asia ${ }^{6}$

\begin{tabular}{|c|c|c|}
\hline Countries & ADB (\%) & AIIB (\%) \\
\hline China & 5.4 & 26.9 \\
\hline Japan & 12.8 & - \\
\hline Korea, ROK & 4.3 & 3.6 \\
\hline Russia & - & 6.1 \\
\hline Australia & 4.9 & 3.5 \\
\hline Indonesia & 4.6 & 3.3 \\
\hline Others & 12.9 & 7.3 \\
\hline Total & 44.9 & 50.7 \\
\hline
\end{tabular}

Source: writer's compilation ${ }^{7}$

The feature proposed by the AIIB managed to attract most of most East Asian countries. However, it does not automatically make the countries in East Asia to join as followers. As we can see in (table 2), the proportion of East Asian countries in the region is bigger in the AIIB. Of course, the dominant position of China is clear. However, it does not stop other members to join the AIIB because it provides better room to gain benefit compare to the ADB's.

In addition, several countries such as Indonesia, Malaysia, the Philippines, and Thailand are considered as a 'Group C' in ADB's classification (ADB, 2013). It means they are only allowed to gain funding through Ordinary Capital Resources (OCR). The OCR is a program by ADB that provides long-term loans at a quasi-market rate (Kawai, 2015). The countries that have been mentioned is at the level of the middle-economy, therefore, by joining AIIB, they are able to look for a softer loan that can benefit their development program.

In summary, we can see how Japan's leadership leaves several flaws and room for improvement that makes China take advantage of by creating AIIB. The AIIB itself, try to fill from two sides: fulfilling demands of development funds and creating a better management of MDB in the region. The establishment of the AIIB then, followed by followership of the East Asian countries, is able to give the chance of China to catch-up with Japan's position in leadership of the region.

\section{Conclusion}

The regionalism in East Asia is in a stagnant condition where two leaders, Japan and China, exist. Japan has the advantage of becoming early movers owed to their miracle of economic development. Thus, creates Japan as the leader for the economic development in East Asia.

\footnotetext{
${ }^{6}$ Consist of: China, Japan, Korea, Hong Kong, Russia, Australia, Brunei, Cambodia, Indonesia, Lao, Malaysia, Myanmar, New Zealand, the Philippines, Singapore, Thailand, Timor-Leste, Vietnam, and Taipei. 7two sources: 1. ADB shareholders and voting power: https://www.adb.org/sites/default/files/institutionaldocument/237881/oi-appendix1.pdf ; 2. AllB shareholders and voting power: https://www.aiib.org/en/aboutaiib/governance/members-of-bank/index.html ; number may not sum precisely because of rounding.
} 
China rise, however, is not well responded by Japan who have been dealing with regional leadership since the first effort in regional integration in East Asia.

China then decides to take multiple initiative programs but always been managed to be countered by Japan in its process. Although the establishment of the ACFTA is considered as a 'winning' position by most scholars, it does not last long until Japan managed to disturb its position in the EAS.

China then sees an opportunity to become a leader that is by forming MDB for the region. The existing $\mathrm{MDB}$, the $\mathrm{ADB}$, has existed since 1966 but there are some rooms of improvement that China can take advantage. China's main aim in forming the AIIB is not too far to challenge U. S's position in the region, instead, China is aiming to become the regional leader of East Asia by looking for acceptance or followership in the region.

As mentioned in the introduction session, there are three main reasons. First, China is trying to provide the infrastructure development fund that is highly demanded by Asian region as whole and East Asia in particular. Second, China long effort in recent two decades is gaining followership through its program such as APT, ACFTA, and EAS although the last one is considered as failure of diplomacy of China. Third, to attract other states, China develops a new regulation that gives improvement over the existing MDB and manages to gain followership from the whole region of East Asia, except Japan.

Looking at the reasoning, this writing concludes that China is still only aiming to become regional leader in the scale of East Asia. To become a global level power and challenge the U.S hegemony in the world, it may need one or two stages above the establishment of the regional MDB.

\section{References}

Åberg, John H S. 2016. “A Struggle for Leadership Recognition: The AIIB, Reactive Chinese Assertiveness, and Regional Order +." Contemporary Chinese Political Economy and Strategic Relations: An International Journal 2(3): 1125-71.

ADB. (1966, August 22). ADB. Retrieved from ADB.org: https://www.adb.org/sites/default/files/institutional-document/32120/charter.pdf

ADB. (2013, September 4). Operations Manual Bank Policies. Retrieved from ADB.org: https://www.adb.org/sites/default/files/page/30786/files/oma1.pdf

ADB. (2013). Who Will Pay Asia's 8 Trillion Infrastructure Gap. Retrieved April 4, 2016, from http://www.adb.org/news/infographics/who-will-pay-asias-8-trillioninfrastructure-gap

ADB. (2013, September 30). Who Will Pay Asia's 8 Trillion Infrastructure Gap. Retrieved April 4, 2016, from ADB.org: http://www.adb.org/news/infographics/who-will-payasias-8-trillion-infrastructure-gap 
ADB. (2016, December 31). Capital Structure. Retrieved from ADB.org: https://www.adb.org/site/investors/credit-fundamentals/capital-structure

ADB. (2017). Shareholders of ADB. Retrieved from Asian Development Bank: https://www.adb.org/site/investors/credit-fundamentals/shareholders

AIIB. (2016). AIIB Articles of Agreement. Retrieved from AIIB.org: https://www.aiib.org/en/about-aiib/basic-documents/_download/articles-ofagreement/basic_document_english-bank_articles_of_agreement.pdf

AIIB. (2017, December 19). AIIB Members and Prospective Members of the Bank. Retrieved from AIIB.org: https://www.aiib.org/en/about-aiib/governance/members-ofbank/index.html

AIIB. (2017, March 21). Operational Policy on Financing. Retrieved from AIIB.org: https://www.aiib.org/en/policies-strategies/_download/operationpolicy/policy_operational_financing_new.pdf

ASEAN. (2015, October). ASEAN-China Free Trade Area. Retrieved from Asean.org: http://www.asean.org/storage/images/2015/October/outreachdocument/Edited\%20ACFTA.pdf

Ba, A. (2014). Is China Leading? China, Southeast Asia and East Asian Integration. Political Science, 66(2), 143-165.

Choi, Y. J. (2007). Northeast Asian Regional Integration: Theoretical Perspectives, Current Realities, and Future Prospects. The Korean Journal of International Relations, 47(5), 113-129.

Chung, C.-P. (2013). China and Japan in "ASEAN Plus" Multilateral Arrangements: Raining on the Other Guy's Parade. Asian Survey, 53(5), 801-824.

Dent, C. (2008). East Asian Regionalism. New York: Taylor \& Francis Routledge.

Dent, C. (2008). Regional Leadership in East Asia: Towards New Analytical Approaches. In C. M. Dent, China, Japan and Regional Leadership in East Asia (pp. 275-305). Cheltenham: Edward Elgar.

Dent, C. (2008). The Asian Development Bank and Developmental Regionalism in East Asia. Third World Quarterly, 29(4), 767-786.

Dent, C. (2008). What region to lead? Developments in East Asian regionalism and questions of regional leadership. In C. Dent, China, Japan and Regional Leadership in East Asia (pp. 3-36). Cheltenham: Edward Elgar.

Haacke, J. (2002). Seeking Influence: China's Diplomacy Toward ASEAN after the Asian Crisis. Asian Perspective, vol.26, no.4, 13-52.

Jones, D. M., \& Smith, M. (2006). ASEAN and East Asian International Relations: Regional Delusion. Cheltenham: Edward Elgar Publishing UK.

Kawai, M. (2015). Asian Infrastructure Investment Bank in the Evolving International Financial Order. In D. Bob, Iasian Infrastructure Investment Bank: China as Responsible Stakeholder? (pp. 5-26). Washington DC: Sasakawa Peace Foundation USA.

Kawai, M. (2015). Asian Infrastructure Investment Bank in the Evolving International Financial Order. In D. Bob (Ed.), Asian Infrastructure Investment Bank: China as Responsible Stakeholder (pp. 5-25). Washington: Sasakawa Peace Foundation USA. 
Keohane, R. (1982). The Demand for International Regimes. In S. Krasner, \& S. Krasner (Ed.), International Regimes (8th ed., pp. 141-171). New York: Cornell University Press.

Keohane, R. (1984). After Hegemony: Cooperation and Discord in the World Political Economy. New Jersey: Princeton University Press.

Kim, H. J., Ping, L. P., \& Ariff, M. R. (2011). East Asian Developments and Contrasting Views among ASEAN Member Nations over East Asian Regionalism. The Korean Journal of Defense Analysis, 23(3), 387-402.

Lee, J.-S. (2004). ASEAN+3 and the New Regional Order in East Asia: Political Consequences of Regional Cooperation. Korean Political Science Review, 38(4), 2542.

Lee, M. H., \& Cheong, I. (2011). A Critical Review on Regional Integration Processes in East Asia. Journal of International Logistics and Trade, 9(2), 33-55.

Lincoln, E. J. (2004). East Asian Economic Regionalism. Washington D.C.: The Brookings Institution.

Lloyd, P., \& Lee, H.-H. (2001). Subregionalism in East Asia and Its Relationship with APEC. Korea and the World Economy, 2(2), 211-227.

Nakamura, T. (2009). Proposal of the Draft Charter of the East Asian Community: An Overview and the Basic Principles. In T. Nakamura (Ed.), East Asian Regionalism from a Legal Perspective (pp. 193-214). New York: Routledge.

Park, J.-S. (2012). Regional Leadership Dynamics and East Asian Financial Cooperation. Journal of Asia-Pacific Studies, 19(1), 225-256.

Park, S.-H., \& Kim, H.-Y. (2006). Increasing sub-regionalism within APEC and the Bogor Goals. Koreanische Zeitschrift fuer Wirtschaftswissenschaften, 24(3), 143-168.

Park, Y.-i. (2007). How Feasible is East Asia-Only Regional Integration: Economic Imperative and Political Impracticality. New Vision for Asia-Europe Economic Cooperation (pp. 37-54). Incheon: Jungseok Research Institute of International Logistics and Trade.

Pedersen, T. (2002). Cooperative Hegemony: Power, Ideas and Institutions in Regional Integration. Review of International Studies, 28(4), 677-696.

Peng, L. (2013). Japan's Relations with Southeast Asia: The Fukuda Doctrine and Beyond. Oxon: Routledge.

Rathus, J. (2008). China, Japan and Regional Organisations: the Case of the Asian Development Bank. Japanese Studies, 28(1), 87-99. doi:10.1080/10371390801939112

$\mathrm{Vu}, \mathrm{T}$. M. (2017). International leadership as a process: The case of China in Southeast Asia. Revista Brasileira de Politica Internacional, 60(1), 1-21.

Wan, M. (2016). The Asian Infrastructure Investment Bank. New York: Palgrave Macmillan. Zha, D. (2002). The Politics of China-ASEAN Economic Relations: Assessing the Move Toward a Free Trade Area. Asian Perspective, 26(4), 53-82. 